Ann. Biol. anim. Bioch. Biophys., 1978, 18 (2 B), 435-440.

\title{
Oocyte maturation within stimulated immature bovine follicles in vivo
}

\author{
by W. D. FOOTE, C. D. MILLS, D. A. PHELPS, F. D. TIBBITTS \\ Max C. Fleischmann College of Agriculture, \\ University of Nevada, Reno, Nevada 89507, USA.
}

\begin{abstract}
Summary. Treatment of forty prepuberal heifers with pregnant mare serum gonadotrophin (PMSG), follicle stimulating hormone (FSH) and each of these gonadotrophins plus luteinizing hormone (LH) resulted in follicular development and oocyte maturation. The follicles were categorized by sizes : small 4-9 $\mathrm{mm}$; medium $10-14 \mathrm{~mm}$ and large $15-20 \mathrm{~mm}$. The greatest numbers of measured follicles were in the heifers treated with FSH but the greatest numbers of large and medium follicles were in the PMSG treated heifers. Resumption of oocyte meiosis was greater in the PMSG treated heifers than in those given FSH. Treatment with LH increased the number of oocytes undergoing meiosis in both PMSG and FSH treated heifers. The percentage resuming meiosis increased with increased follicle size in the PMSG groups but not in the FSH groups.
\end{abstract}

\section{Introduction.}

Ovarian follicular development in prepuberal heifers due to gonadotrophin treatment has been demonstrated (Casida et al., 1943 ; Rowson, 1951). This information has been used to study ovulation and fertilization rates in heifers treated with gonadotrophins (Black ef al., 1953 ; Marden, 1953 ; Howe ef al., 1962 ; Jainudeen et al., 1966 ; Onuma et al., 1969 ; Onuma ef al., 1970). These studies show that the heifer can be stimulated to ovulate and that a proportion of these oocytes can be fertilized. Work has been carried out pertaining to follicular stimulation and proportions of various sizes of follicles (Jainudeen ef al., 1966), but there is a paucity of information on oocyle maturation in relation to induced follicle development. Hunter, Cook and Baker (1976) found that pig oocytes from prematurely induced ovulations had not undergone maturation.

Most of the work to study oocyte maturation in immature follicles has been in vitro. The optimum size follicle for dissection and culture appears to be approximately 1-3 $\mathrm{mm}$ in diameter. Follicles of this size are immature in large animals but usually at a developmental stage receptive to stimulation for pre-ovulatory maturation and ovulation in small animals such as the rat and rabbit. Consequently, cultured follicle of similar sizes but from different species are different in physiological age. Although virtually all oocytes in such follicles are in the dictyate stage, regardless of species, 
differences in their ability to be induced to resume normal meiosis, directly or through follicular influence, may exist. Tsafriri, ef al. (1972) found that cultured pig oocytes increased in percentage undergoing meiosis with an increase in size of the follicles from which they were obtained.

This experiment was designed to determine the influence of gonadotrophin treatments on in vivo follicular development and oocyte meiosis and to relate these two phenomena in prepuberal heifers.

\section{Materials and methods.}

Forty heifers of mixed breeding ranging from 6 to 9 months of age and from 90 to 200 kilograms were used in this experiment. They were determined to be prebuberal by the absence of estrus and corpora lutea. The animals were stratified by weight and assigned to five experimental groups. All of the heifers were maintained together and fed good quality alfalfa hay throughout the experiment.

The heifers were treated starting on day 1 , with gonadotrophins, checked twice daily for estrus, days 1 through 5 and laparotomized on day 6, $120 \mathrm{hrs}$ after initial treatment. Heifers in group 1 were treated with a single intramuscular injection of 2000 IU PMSG. Heifers in group 2 were treated with $75 \mathrm{mg} \mathrm{FSH}$. The FSH was given in a series of subcutaneous injections, $7.5 \mathrm{mg}$ twice daily, days 1 through 5 . Group 3 heifers were given the same PMSG treatment as in group 1 plus $20 \mathrm{mg}$ LH intravenously on day 5, 24 hrs before laparotomy. Group 4 heifers received the same FSH treatment as group 2 and the same LH treatment as group 3. Heifers in group 5 were control animals and received an injection of physiological saline solution intramuscularly on day 1. They were also laparotomized on day 6.

At laparotomy, the ovaries of all of the heifers were exteriorized and measured. All follicles $4 \mathrm{~mm}$ in diameter or larger were measured, counted and grouped into 3 size categories as follows : 4 to $9 \mathrm{~mm}$ (small) 10 to $14 \mathrm{~mm}$ (medium) and 15 to $20 \mathrm{~mm}$ (large). A minimum follicle diameter of $4 \mathrm{~mm}$ was established because aspiration of smaller follicles in situ was not consistently achievable. The number of follicles in each size category was recorded. The occurrence of ovulation was detected by observation of the ovaries for newly formed corpora lutea.

The follicles were aspirated using a $10 \mathrm{cc}$ syringe with a 20 gauge needle. The syringe contained à $1 \%$ heparin solution to prevent clotting of any blood that was aspirated with the follicle fluid. The aspirated follicle fluid from different size follicles was pooled within each size group. Using a dissecting microscope the oocytes were recovered from the follicle fluid and placed in fixative for subsequent preparation for light microscopic examinatin. The oocytes were observed for nuclear changes and classified according to the following stages of maturation : dictyate, pre-metaphase, metaphase I, anaphase-telophase and metaphase II.

\section{Results.}

Follicular development of the heifers of the different treatment groups is shown in table 1. All treatments were effective in increasing the number of follicles in all 
sizes. No follicle larger than $20 \mathrm{~mm}$ was observed. Although most of the measured follicles of the untreated heifers were rated small, relatively few follicles were large enough to classify. This suggests that most of the follicles in the untreated animals were less than $4 \mathrm{~mm}$ and that most of the measured follicles in the treated heifers had enlarged in response to exogenous gonadotrophin treatment.

TABLE 1

Follicular development in gonadotrophin treated heifers

\begin{tabular}{|c|c|c|c|c|c|}
\hline \multirow{2}{*}{ Item } & \multicolumn{5}{|c|}{ Treatment } \\
\hline & PMSG & $\mathrm{FSH}$ & PMSG + LH & $\mathrm{FSH} \dashv \mathrm{LH}$ & Untreated \\
\hline $\begin{array}{l}\text { Avg. No. follicles......... } \\
\text { Range ................. } \\
\text { p. } 100 \text { large follicles } \ldots \ldots \\
\text { p. } 100 \text { med. follicles } \ldots \ldots \\
\text { p. } 100 \text { small follicles } \ldots \ldots\end{array}$ & $\begin{array}{c}52 \\
18-161 \\
14 \\
66 \\
20\end{array}$ & $\begin{array}{c}65 \\
16-152 \\
7 \\
44 \\
49\end{array}$ & $\begin{array}{c}56 \\
20-94 \\
16 \\
55 \\
29\end{array}$ & $\begin{array}{c}71 \\
20-92 \\
8 \\
27 \\
65\end{array}$ & $\begin{array}{c}16 \\
10-31 \\
0 \\
2 \\
98\end{array}$ \\
\hline
\end{tabular}

PMSG was more effective than FSH in causing follicular development to the large size. The addition of LH with either PMSG or FSH did not enhance this follicular growth.

Some heifers ovulated during the treatment period, including one of the largest untreated animals. Apparently some of the largest heifers were approaching puberty at the beginning of the experiment and the effect of heifer size on ovulation may be confounded with that of treatment.

Table 2 shows the stages of maturation of the oocytes. None of the oocytes from untreated heifers had resumed meiosis from the dictyate stage. Treatment with $\mathrm{LH}$ increased the number of oocytes resuming meiosis and the number reaching Metaphase II, for both PMSG and FSH within all follicle sizes.

The greatest response was in the PMSG + LH group where the oocytes of $70 \mathrm{p}$. 100 of the total follicles had progressed beyond the dictyate stage. Only 19 p. 100 of the total oocytes from the PMSG only group had resumed meiosis. Eighty three percent of the oocytes from the large follicles in the PMSG + LH group of heifers were undergoing meiosis and 78 p. 100 of the medium size follicles, were maturing. Although this percentage dropped appreciably in the small follicles, treatment did appear to induce maturation in some of these follicles. The percentage of oocytes undergoing maturation in the small follicles in the PMSG, FSH, PMSG $+\mathrm{LH}, \mathrm{FSH}+\mathrm{LH}$ and no treatment, were 13, 18, 45, 21 and 0 respectively. The percentage of oocytes resuming meiosis increased with increased follicle size in the PMSG groups but not in the FSH groups.

It appears that both the PMSG and FSH treatments used induce follicle growth and some degree of oocyte maturation with PMSG being the more effective. Oocyte maturation occured in some of the growing follicles evens though they were considerably smaller than follicles preparing for ovulation in an estrous period of an untreated animal. Addition of LH during the treatment period appeared to increase oocyte 
maturation. This $\mathrm{LH}$ effect may be similar to the relationship of the $\mathrm{LH}$ surge to oocyte maturation during the estrous period of untreated animals. However, the follicle involvement and normalcy of oocyte maturation in small follicles following gonadotrophin treatment needs additional study.

TABLE 2

Meiotic stages of oocytes from heifers treated with different hormones

\begin{tabular}{|c|c|c|c|c|c|c|c|}
\hline \multirow[b]{2}{*}{ Treatment } & \multirow[b]{2}{*}{ Follicles } & \multicolumn{6}{|c|}{ Percentage in each meiotic stage } \\
\hline & & $\begin{array}{l}\text { No. of } \\
\text { oocytes }\end{array}$ & Diclyate & Pre-Met. & Metaphase I & Anaphase-Telophase & Met. II \\
\hline \multicolumn{8}{|l|}{ PMSG } \\
\hline & Total ..... & 83 & 81 & 0 & 17 & 0 & 2 \\
\hline & Large & 13 & 62 & 0 & 23 & 0 & 15 \\
\hline & Medium .. & 40 & 83 & 0 & 17 & 0 & 0 \\
\hline & Small .... & 30 & 86 & 0 & 13 & 0 & 0 \\
\hline \multicolumn{8}{|c|}{ The } \\
\hline & Total ..... & 180 & 85 & 4 & 11 & 0 & 0.5 \\
\hline & Large .... & 7 & 100 & 0 & 0 & 0 & 0 \\
\hline & Medium .. & 61 & 88 & 3 & 7 & 0 & 2 \\
\hline & Small .... & 112 & 82 & 5 & 13 & 0 & 0 \\
\hline \multicolumn{8}{|c|}{ PMSG + LH } \\
\hline & Total ..... & 155 & 30 & 32 & 16 & 3 & 20 \\
\hline & Large .... & 24 & 17 & 33 & 13 & 13 & 25 \\
\hline & Medium .. & 91 & 22 & 37 & 15 & 1 & 24 \\
\hline & Small .... & 40 & 55 & 18 & 20 & 0 & 7 \\
\hline \multicolumn{8}{|l|}{$\mathrm{FSH} \dashv \mathrm{LH}$} \\
\hline & Total ..... & 105 & 61 & 15 & 17 & 1 & 6 \\
\hline & Large .... & 15 & 33 & 7 & 47 & 0 & 13 \\
\hline & Medium ... & 24 & 29 & 46 & 17 & 4 & 4 \\
\hline & Small $\ldots$. & 66 & 79 & 6 & 11 & 0 & 0 \\
\hline \multicolumn{8}{|l|}{ Untreated } \\
\hline & Total ..... & 33 & 100 & 0 & 0 & 0 & 0 \\
\hline & Large .... & 0 & - & - & - & - & - \\
\hline & Medium .. & 1 & 100 & 0 & 0 & 0 & 0 \\
\hline & Small ... & 32 & 100 & 0 & 0 & 0 & 0 \\
\hline
\end{tabular}

\section{Discussion.}

Ovarian stimulation using PMSG and FSH compares favoraboly with results obtained by Jainudeen et al. (1966), Onuma et al. (1969), and Onuma ef al. (1970), when comparing their number of ovulations to number of follicles stimulated in this experiment. Also paralleling their work was the increase in percent of ovulation that they obtained as compared to the increase in the percent of oocytes resuming meiosis obtained in this experiment when LH was used in conjunction with PMSG or FSH.

The dosage levels of gonadotrophins required to stimulate follicular development and oocyte maturation appear to be similar to the levels required for superovulation of the prepuberal heifer (Howe et al., 1962 ; Jainudeen ef al., 1966 ; Onuma ef al., 1969 ; Onuma ef al., 1970). 
These results are compatible with those of Testart (1972), which suggest that follicles smaller than $4 \mathrm{~mm}$ provide a storage population of follicles which can be stimulated to grow.

Observations were not made for proportion of atretic follicles in this study. Meiosis has been shown to appear in atretic follicles (Henricson and Rajakoski, 1962). Virtually no meiosis was found in the follicles of the untreated heifers. Arrau (1974) reported that a substantial number of oocytes from smaller follicles from prepuberal heifers were beyond the dictyate stage. This difference may be due to a much smaller population of atretic follicles in this study, a majority of the atretic follicles being smaller than those aspirated, or the recovery rate of oocytes from aspirated atretic follicles being very low.

It is possible that the apparent increased maturation rate of oocytes in small and medium size follicles from LH treated heifers was due to follicular atresia. However, although the follicles were not recovered and examined microscopy, the cumulus cells obtained with these oocytes appeared normal.

The relationship between follicular and oocyte maturation is reviewed by Thibault (1977). Caution must be taken in comparing endogenous endocrine control of these phenomena with exogenous hormone stimulated responses.

\section{$27^{e}$ Congrès infernational des Sciences physiologiques, Symposium " Germ and somatic cell inferaction 》 Paris, 21-23 juillet 1977.}

Acknowledgements. - Contribution from the Nevada Agricultural Experiment Station, University of Nevada, Reno, Journal Series Number 394. The FSH for this experiment was provided by Burns-Biotec Laboratories, Oakland, California. The $\mathrm{LH}$ for this experiment was provided by the National Institute of Health. Technical assistance for this research was provided by Dr. D. Hanks and Phyllis Williams.

Résumé. Le traitement de 40 génisses prépubères avec PMSG, FSH et ces hormones en combinaison avec $\mathrm{LH}$, provoque le développement folliculaire et la maturation de l'ovocyte. Les follicules ont été classés en 3 tailles, les petits de 4 à $9 \mathrm{~mm}$, les moyens de 10 à $14 \mathrm{~mm}$ et les grands de 15 à $20 \mathrm{~mm}$. Le plus grand nombre de follicules de ces 3 catégories a été obtenu avec FSH seule, mais le plus grand nombre de moyens ef de grands follicules a été observé après l'action de PMSG qu'après FSH, mais le traitement par LH augmente cette fréquence à la fois après traitement par FSH et par PMSG. Le pourcentage d'ovocytes reprenant leur méiose augmente avec la taille des follicules pour les génisses recevant PMSG, mais pas chez celles recevant FSH.

\section{References}

ARRAU J., 1974. Cinétique folliculaire et maturation ovocytaire chez le veau traité par l'acétate de fluorogestone et la PMSG. Ann. Biol. anim. Bioch. Biophys., 14, 633-650.

BLACK W. D., ULBERG L. C., CHRISTIAN R. E., CASIDA L. E., 1953. Ovulation and fertilization in the hormone-stimulated calf. J. Dairy Sci., 36, 274.

CASIDA L. E., MEYERS R. K., McSHAN W. H., WISNICKY W., 1943. Effects of pituitary gonadotrophins on the ovaries and the induction of superfecundity in cattle. Am. J. vet. Res., 4, 76-94.

HENRICSON B., RAJAKOSKI E., 1962. Meiosis in atretic Graafian follicles in cattle. Cornell Vet., 52, 78-83. 
HOWE G. R., BLACK D. L., FOLEY R. C., BLACK W. G., 1962. Ovarian activity in prepuberal dairy calves. J. Anim. Sci., 21, 82.

HUNTER R. H. F., COOK B., BAKER T. G., 1976. Dissociation of response to injected gonadotrophin between the Graafian follicle and oocyte in pigs. Nature, 260, 156-158.

JAINUDEEN M. R., HAFEZ E. S., LINEWEAVER J. A., 1966. Superovulation in the calf. J. Reprod. Ferf., 12, 149-153.

MARDEN W. G. R., 1953. The hormone control of ovulation in the calf. J. agric. Sci., 43, 381-406.

ONUMA H., HAHN J., FOOTE R. H., 1970. Factors affecting superovulation, fertilization and recovery of superovulated ova in prepuberal cattle. J. Reprod. Fert., 21, 119-126.

ONUMA H., HAHN J., MAURER R. R., FOOTE R. H., 1969. Repeated superovulation in calves. J. Anim. Sci., 28, 634-637.

ROWSON L. E., 1951. Methods of inducing multiple ovulations in cattle. J. Endocr., 7, 260.

TESTART J., 1972. Réponse folliculaire de veau femelle impubère à divers traitements de gonadotropine sérique associée ou non à un progestagène. Ann. Biol. anim. Bioch. Biophys., 12, 397409.

THIBAULT C., 1977. Are follicular maturation and oocyte maturation independent processes? J. Reprod. Fert., 51, 1-15.

TSAFRIRI A., LINDNER H. R., ZOR U., LAMPRECHT S. A., 1972. In vitro induction of meiotic division in follicle-enclosed rat oocytes by LH cyclic AMP and prostaglandin E2. J. Reprod. Fert., 31, 39-50. 